\title{
Apoptosis Inhibitor UL38
}

National Cancer Institute

\section{Source}

National Cancer Institute. Apoptosis Inhibitor UL38. NCI Thesaurus. Code C129674.

Apoptosis inhibitor UL38 (331 aa, 37 kDa) is encoded by the cytomegalovirus UL38

gene. This protein plays a role in the inhibition of host cell apoptosis. 